\title{
DEPOIMENTO SOBRE MINHA VIVÊNCIA NA ANTROPOLOGIA DA UFRGS
}

\section{Sérgio Alves Teixeira}

\section{Universidade Federal do Rio Grande do Sul - Brasil}

Resumo: Este depoimento, a partir da vivência docente e administrativa do autor na antropologia da UFRGS no período de 1962 a 1997, apresenta um histórico abrangente do que aí se passou neste espaço de tempo, dando ênfase ao processo de sua construção como centro avançado de ensino e investigação.

Abstract: In this personal testimony, the author recounts his participation, between 1962 and 1997, as teacher and administrator in the program of anthropology at the Federal University of Rio Grande do Sul. Covering a vast amount of information, he outlines the steps which led to the formation of an advanced center of teaching and research in Brazilian anthropology.

Quando Ruben George Oliven, mentor maior do Projeto História da Antropologia na Universidade Federal do Rio Grande do Sul, e Maria Eunice de Souza Maciel, organizadora deste número de Horizontes Antropológicos, dedicado a histórias da Antropologia, me comunicaram, dia 30 de julho de 1997 que "decidiram que eu deveria escrever um depoimento sobre minha vivência de 35 anos atuando na Antropologia da UFRGS”, aceitei na hora, por entender que, de fato, teria com o que contribuir. Todavia hoje, passados apenas dois dias, iniciando a tarefa de cumprir o compromisso tão livremente aceito, experimento o sentimento que atinge de modo geral, quem é solicitado a falar sobre si: um certo desconforto.

O que me faz acreditar que possa contribuir com este depoimento para o Projeto da História da Antropologia na UFRGS, mais do que o período de 35 anos, em si, foram as circunstâncias do tempo em que ele foi vivido.

Ainda que a condição de autor e ator justifique a profusão de eu no depoimento que se seguirá, procurarei não descumprir o compromisso tão próprio da Antropologia com o outro. Mesmo assim peço a compreensão benevolente dos possíveis leitores para os tantos eu que surgirão daqui para a frente. Estendo o mesmo pedido para as omissões e imprecisões de certos dados, o que, e muitos casos, além da dificuldade/impossibilidade de 
recuperá-los se dá porque dispensam precisá-los e, também, pela conveniência de não atingir pessoas, com avaliações atuais, em função de concepções e ações passadas, tudo num quadro carregado de Subjetividade.

A primeira parte deste depoimento será como que uma etnografia, bastante minuciosa, enquanto a segunda se constituirá de algumas considerações.

O primeiro fato a registrar neste depoimento são as circunstâncias que marcam meu ingresso no corpo docente da Antropologia da UFRGS, em março de 1962.

Em decorrência do falecimento, em 1961, do Professor Balduíno Rambo, fundador (em 1942) e catedrático da disciplina, o mesmo foi substituído pelo seu assistente, professor Pedro Ignácio Schmitz, que iniciou como professor de Língua Tupi, matéria obrigatória no curso de História. Como integrava a disciplina só um outro professor, Arthur Blásio Rambo, tornou-se imperioso admitir mais um docente. Porque na época a Antropologia integrava o Departamento de História, tanto a substituição do professor Balduíno Rambo, como a contratação do novo docente, com a indicação de meu nome, foram nele definidas.

Verdadeiramente só agora, passados 35 anos, sou levado apensar seriamente o que teria conduzido à minha indicação. Tudo me faz supor que tenham concorrido para tal uma certa competência, que incluía experiência no magistério secundário, simpatia por mim, estar temporalmente ainda próximo, pois concluíra a Licenciatura em História no final do ano anterior e, ser homem. Minha turma, do ingresso à conclusão do curso, foi composta por 8 alunas e três alunos. Destes um já trabalhava como monitor de outra disciplina e o outro conduzia seus estudos com marcada irregularidade.

A relevância que atribuo ao fato de ser homem se explica porque, assim como se dava com o catedrático falecido, os outros dois professores da Antropologia eram padres jesuítas, o que, penso agora, inibiria a escolha de uma mulher para trabalhar com eles.

Minha integração ao corpo docente da Antropologia rompeu com o arraigado paroquialismo que aí até então imperava (presente também em diversas áreas na Universidade, sobretudo com base no parentesco).

Balduíno, que indicou os outros dois, também era irmão de Arthur. Além de ser eu o primeiro docente leigo da Antropologia também fui o primeiro a ser indicado por um colegiado, com nomeação em estágio probatório por um ano, confirmada depois com aprovação em prova de conhecimentos e de didática. Registro também que a indicação de meu nome não se deu por iniciativa do novo catedrático. 
A fidelidade aos fatos me obriga a abordar as circunstâncias que envolveram a realização de tais provas. De conformidade com as normas que regulamentavam a questão, o professor catedrático de Antropologia, por julgar satisfatório o meu desempenho até então, definiu os conteúdos e o cronograma para as referidas provas, em dois dias consecutivos, do que deu ciência para o Departamento e para mim, com trinta dias de antecedência, da data da primeira prova, a escrita. Por isto, quando o catedrático, sem qualquer justificativa, resolveu me dispensar a uma semana da realização da primeira prova, o Departamento não referendou sua decisão. De minha parte, eu só tomei conhecimento da situação na véspera da data fixada para aquela prova, que foi suspensa. Como o catedrático se mostrava irredutível em justificar ou reconsiderar sua decisão, o Departamento, que não tinha competência para revogá-la, entendeu que eu deveria recorrer à Congregação da Faculdade, o que foi feito, com sucesso. As provas foram realizadas cerca de três semanas mais tarde, com a banca examinadora sendo composta pelos professores catedráticos, Dante de Laytano, de História do Brasil; Francisco Machado Carrion, de História Moderna e Contemporânea e Othelo Sanchez Laurent, de História Antiga e Medieval.

Ainda que eu tenha recebido a solidariedade ativa de todos os integrantes do Departamento, a exceção de dois deles, é imperioso destacar a atuação dos professores Othelo Sanchez Laurent e de seu assistente, Earle Diniz Marcarthy Moreira. Este foi a principal força propulsora de todo o processo e aquele assumiu minha causa junto à Congregação. Também é imperioso dizer que todos os colegas do Departamento que me apoiaram não o fizeram por amizade, mas por espírito de justiça e que do episódio só restou o meu reconhecimento a todos eles.

Em treze de abril de 1962 enfrentei minha primeira aula, tratando de folclore, para uma turma do curso de Geografia, composta por companheiros de lides estudantis e mesmo colegas de aula, de até poucos meses antes. A ansiedade, de parte a parte, estabeleceu uma cumplicidade que muito me ajudou na caminhada que ali se iniciava, a qual sempre serei reconhecido.

É de justiça registrar que tão logo o professor Pedro Ignácio Schmitz assumiu a cátedra, imprimindo sua marca pessoal, ele provocou profunda alteração nas orientações teórica e pedagógica definidas por seu antecessor. Assinalo que mexer com tudo isto, por si só, representou uma ousadia. Vale como contraponto, o caso de um outro professor que assumindo outra cátedra em situação análoga, na mesma ocasião, ainda que instigado por todo o seu Departamento para mudar técnicas de ensino, programas e orientações teóricas, inibido, conservou tudo o que fora definido por seu antecessor. 
No que respeita às alterações impostas pelo professor Schmitz, mais do que o abandono das aulas magistrais, caracterizadas pela leitura de sebentas, com interrupções para improváveis manifestações dos alunos, cabe destacar as alterações nos conteúdos estudados e na orientação teórica com que eram considerados. O estudo monográfico de grupos primitivos ou de regiões culturais cederam lugar aos grandes segmentos da vida sócio-cultural, parentesco, economia, religião, arte, etc., num quadro amplamente comparativo. O histórico-culturalismo da Escola de Viena foi substituído pelo culturalismo/funcionalismo, mais marcadamente norte-americano. Nas classes o efeito mais imediato de tais mudanças foi a adoção do livro de Felix Keesing, Antropologia Cultural, da Fundo de Cultura, como manual. Seu uso era de tal modo intenso que nossa biblioteca, que usualmente mantinha em seu acervo apenas um exemplar de cada obra, não teria deste menos de dez exemplares. Como este livro teve, ao que sei, no mínimo três edições no Brasil, na década de 60, é de supor que seu uso tenho sido intenso em muitos outros pontos do país. Como a época era favorável ao uso de manuais, sobrou espaço para se trabalhar com outros, como O homem: uma introdução à Antropologia, de Ralph Linton; El hombre en el mundo primitivo, de E. A. Hoebel; Introducción a la Antropologia, de Ralph Beals e Harry Hoijer; Antropologia, de C. Kluckhonh; Antropologia Cultural, de Melville Herskovits. O relativismo cultural tão bem desenvolvido neste livro, apesar de provocar certas objeções entre colegas da disciplina, ajudou a abrir muitas cabeças, inclusive a minha.

Ainda assim e já nos primeiros tempos, também trabalhei com coletâneas e monografias. Tenho presente ter trabalhado com Readings in Anthropology, de Morton H. Fried; Elements of social organization, de Raymond Firth; Explorations in Cultural Antrhopology, de Ward H. Goodenough (ed.); Antropologia Social, Godfrey Lienhardt; Growing up in New Guinea, de Margaret Mead; Padrões de cultura, de Ruth Benedict; Uma teoria científica da cultura, de B. Malinowski; Antropologia Estrutural, de Radcilffe-Brown; Antropologia Econômica, de Melville Herskovits; Traditional cultures: and the impact of technological chan$g e$, de George Foster. Com isto não estou dizendo que os demais colegas da disciplina só trabalhassem com os manuais. No caso do professor Schmitz, sem dúvida, não era o que ocorria. Curiosamente e não sei explicar por que, Lévi-Strauss e outros autores franceses entraram bem mais tarde em minhas preocupações.

A propósito de livros é oportuno registrar que o acervo de Antropologia na biblioteca foi em muito melhorado pela ação do professor Schmitz. Ele acompanhava os novos lançamentos com grande interesse. Teorias e críticas 
lhe despertavam especial atenção. Era usual quando eu procurava nas livrarias de Porto Alegre por livros de Antropologia, algum funcionário dizer que um padre também estava sempre buscando tais livros. Sempre tive certeza quem era a pessoa a quem assim se referiam.

Por sua dedicação ao estudo e competência, o professor Schmitz se constitui em marco destacado na História da Antropologia na UFRGS e no Rio Grande Sul como um todo. Nos diversos Encontros de Professores de Antropologia do Estado, estimulados por ele e realizados anualmente nos anos 60 e 70, sua projeção se evidenciava. Era ouvido com respeito e ouvia com interesse. $\mathrm{Na}$ área da arqueologia indígena ele desfruta de renome internacional. A foto a seguir mostra um momento de descontração durante o Encontro de Caxias do Sul.

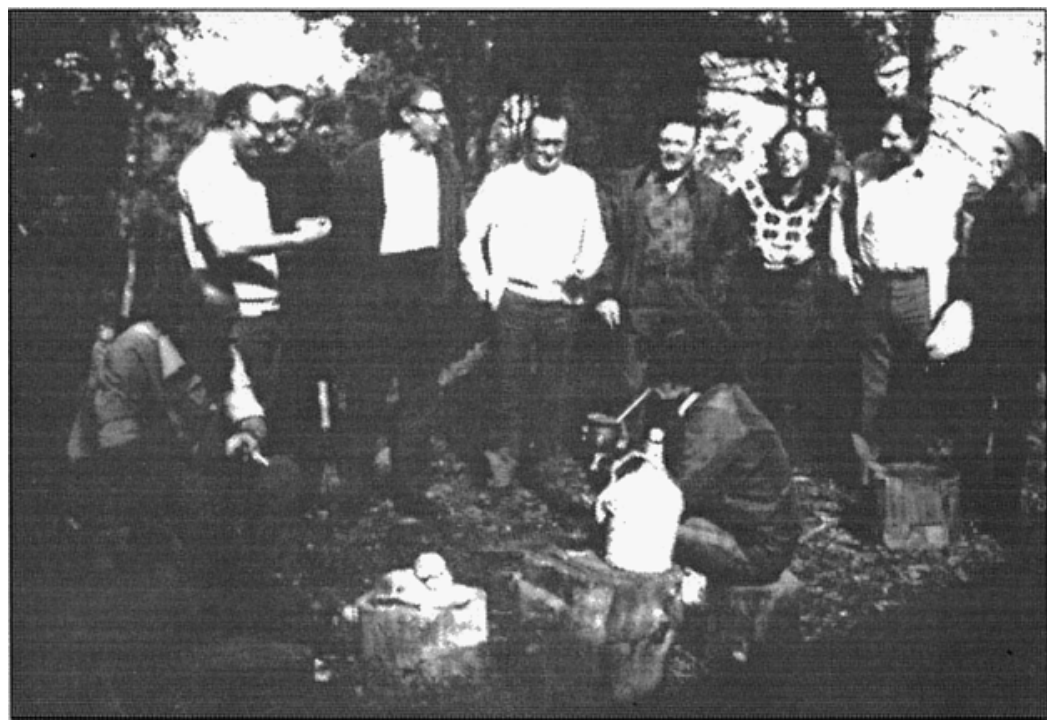

$5^{\circ}$ Encontro Estadual de Antropologia e Arqueologia - Caxias do Sul - Abril/1972. Da direita para a esquerda: Carmem Maria Teixeira, Sérgio Teixeira, Maria Noemi Brito, Danilo Lazzarotto, Guilherme Nane, Pedro Ignácio Schimitz, João Alfredo Rohr. Sentados: Ervino Barth, Fernando La Salvia (foto do arquivo Projeto História da Antropologia no RS - UFGRS).

Ainda que as aulas magistrais tivessem sido abolidas persistiu um resquício daquele tempo, ao menos para mim, e por determinação do catedrático: o compromisso de elaborar sebentas sobre certos temas a serem considerados 
em minhas aulas. Esta foi, talvez, sua única orientação imperativa em relação a mim. Devo ter preparado umas três ou quatro, ainda em meu primeiro ano, e com alguma contrariedade.

Desde o início trabalhei nos três cursos para os quais a Antropologia era oferecida: Ciências Sociais, História e Geografia. Sempre atuando com integral responsabilidade de regência de classe, como se dava também com os outros professores da disciplina. Embora todos trabalhássemos indistintamente nos três cursos, o de Ciências Sociais logo passou a ser atendido de modo predominante e mesmo exclusivo por mim. Imagino que para isto tenha contribuído o fato deste curso funcionar à tarde (os outros dois eram pela manhã), o que apresentava certa dificuldade para os colegas que residiam na cidade de São Leopoldo, a cerca de 30 km. A admissão de mais um docente, José Joaquim Justiniano Proença Brochado, em 1963 e indicado pelo professor Schmitz, não alterou a situação. Inteiramente voltado para arqueologia indígena não interessou-se em trabalhar com este curso.

Como até 1968 a vinculação departamental estava associada à participação nos cursos em que se atuava, cheguei a integrar, simultaneamente, os Departamentos de Ciências Sociais, Geografia e História, o que teve certa relevância em minha trajetória universitária. Determinado a fazer carreira na Antropologia, sempre fui zeloso no cumprimento de minhas atividades. Residindo até 1968 a menos de $1 \mathrm{~km}$ da Universidade, tinha facilitado meu interesse em participar das reuniões departamentais e da vida acadêmica em geral. Assim, ainda que admitido em regime de 12 horas semanais de trabalho, e trabalhando noutros lugares, tinha presença constante na Universidade, o que não se dava com os demais colegas da disciplina. Tais fatos, associados à administração democrática da disciplina por parte do catedrático, propiciaram que eu adquirisse quase completa autonomia acadêmica e passasse a exercer uma relativa liderança política na Antropologia. Para tal também deve ter contribuído o afastamento do professor Schmitz, por um ano, em 63/64, para realizar um estágio em Viena. Na oportunidade cheguei a ser responsável por cinco turmas.

Por conta de tal autonomia pude romper com a tradição seguida até então na disciplina de centrar atenção na arqueologia indígena, antropologia física e sociedades simples. Sem abandonar as últimas, centrei meus interesses nas sociedades complexas, incluindo-se aí o Brasil urbano e contemporâneo. Permito-me registrar, numa espécie da parênteses, que lembrei agora de belas discussões e belos trabalhos de alunos, sobre temas como carnaval, padrões de namoro, preconceito e discriminação raciais. Fruto da época, também incursionei pelos estudos de comunidades. Entre outros estudos sobre o tema lembro 
de ter trabalhado com os clássicos Uma comunidade amazônica, de Charles Wagley e Uma vila brasileira, de Emílio Willems. Este, por sinal, de passagem por Porto Alegre, almoçou em minha casa, acompanhado de sua esposa, ocasião em que autografou meu exemplar daquele seu livro. Conferindo, agora, vejo que ele não datou, ainda assim tenho certeza que foi no final dos anos 70 .

Minha preocupação com as sociedades complexas levou-me, já em 1963, a montar um programa sobre a África, centrado nos processos de colonização/ descolonização que o continente vivenciava na época. Meio sem saber, enveredava, assim, pelos caminhos da Antropologia Social Inglesa. O curso, oferecido todos os anos, deixou de ser oferecido a partir de 1973, quando me afastei para fazer mestrado na Universidade Estadual de Campinas - UNICAMP.

Com toda a propriedade posso dizer que, na época, o estudo das questões africanas se constituiu numa legítima África. A bibliografia disponível na UFGRS era escassa e desatualizada. Em função disto me pus a campo para adquirir livros, para mim e para a biblioteca. Também saí a cata de pessoas com alguma experiência africana, com condições de contribuir para amenizar minhas dificuldades. E elas apareceram, todas residindo ou de passagem por Porto Alegre. Lembro de diplomatas de países europeus com colônias na África; militares brasileiros que cumpriram missão no Congo, integrando forças da ONU, que intervieram nos conflitos que se seguiram à sua independência; professores franceses e ingleses (um destes era sobrinho de Evans-Pritchard), que atuavam no curso de Letras da UFRGS; exilados políticos de Angola e Moçambique; empresários e simples turistas. Na busca de palestrantes a contribuição dos próprios alunos foi maiúscula. Certamente, alunos e eu, pudemos conversar com não menos de vinte destes abnegados. Todos deram alguma contribuição.

Como a maior parte da literatura que consegui reunir era em inglês, cuja leitura raríssimos alunos dominavam, me vi forçado a fazer diversas traduções mais ou menos resumidas, para uso deles. Além de me exigir um grande esforço, isto também representou uma certa temeridade, porém, com resultado bastante satisfatório. Temeridade porque sendo medíocre meu conhecimento de inglês, de modo quase autodidata, me vi forçado a desenvolver sua leitura. Minha aprendizagem se deu com a leitura de alguns capítulos de Profiles in ethnology, de Elman Service. Aliás, ele foi o primeiro dos diversos antropólogos norte-americanos e ingleses a quem escrevi, solicitando indicações de temas para estudo e bibliografias. Obtive bom retorno, em número de respostas e de contribuições. Sempre contei com a boa vontade de colegas e amigos para verterem minhas cartas para o inglês. Meu empenho no curso, ou melhor dizendo, nos cursos, sobre a África 
foi duplamente recompensado. Primeiro, pela muito boa receptividade por parte dos alunos e pelo que aprendi; segundo pela viagem à África, que pude realizar. Penso que vale a pena registrar como as coisas se passaram.

Lá por abril de 1969 me deparei, em revista de divulgação, com uma ampla matéria sobre Angola, na época sob administração portuguesa, como Província Ultramarina. A referida matéria destacava o entusiasmo de seu Governador com o que lá se passava. Ocorreu-me, então escrever para ele, major Rebocho Vaz, do Exército Português. Minha verdadeira intenção ao escrever-lhe era obter o que de fato sucedeu: o convite para visitar Angola, sem que eu pedisse. Minha estratégia consistiu em apresentar meu curso sobre a África e falar de minha dificuldade em tratar de Angola e dos outros territórios portugueses no continente, pela maneira conflitante como eram considerados na bibliografia. Em função do que lhe fazia três perguntas bem fundamentadas. Lembro que uma delas referia-se ao sentimento nacional português que, dizia ele, naquela revista, animava o conjunto da população angolana. Concluía minha carta dizendo que procedia assim por não ter uma experiência africana e não saber quando e se tal viria a ocorrer. Uns dois meses depois recebi o convite, por conta do Ministério do Exterior de Portugal. Viajei em setembro, via Lisboa, permanecendo duas semanas em Portugal a espera de lugar em voo para Angola. Aí permaneci três semanas, sendo recebido por Rebocho Vaz, que me causou excelente impressão e a quem ofereci o livro O caráter nacional brasileiro, de Dante Moreira Leite. De Angola fui para Moçambique, com uma estadia de duas semanas.

Pelos contatos que pude fazer e pelas numerosas viagens em Portugal e na África, realizei uma muito proveitosa viagem de observação. Deveras, aprendi bastante. Um outro fruto desta viagem, agora na área do simbólico, foi que ela representou para mim, para meus alunos e, também para colegas da Universidade mais chegados a mim, uma espécie de rito de passagem, que me legitimava a tratar de África. Afinal, tinha ido lá.

Registrei minhas observações em um artigo intitulado "A continuidade da presença portuguesa na África”, publicado por Organon, n. 14, 1970, revista da Faculdade de Filosofia da UFRGS. O mesmo também foi publicado, em duas partes, em edições dominicais sucessivas, pelo Correio do Povo, na época o principal jornal do Rio Grande do Sul. Minha primeira publicação foi um artigo intitulado “Antropologia Aplicada”, publicado por Organon, n. 13, em 1968 e elaborado para ser apresentado no primeiro ou segundo Encontro de Professores de Antropologia do Rio Grande do Sul. Creio que na cidade de Ijuí. Com ele também iniciei minha participação ativa em fóruns deste tipo. 
Como ultrapassei o período de um mês concedido para meu afastamento, por dificuldade de conseguir passagem, enfrentei algum contratempo em meu retorno. Embora o Departamento de Ciências Sociais, ao qual eu pertencia desde o ano anterior, aceitasse plenamente minhas ponderações, a secretária da Faculdade de Filosofia pretendeu complicar as coisas. Entendo não ser supérfluo dizer que tratava-se de pessoa antiga no cargo, autoritária e de mentalidade burocrática e cuja influência, por princípio nefasta, excedia às suas atribuições funcionais. Ela jogou inclusive com a inexperiência do novo diretor da Faculdade, que assumiu durante meu afastamento, na situação constrangedora de substituir o anterior, expurgado pelo regime autoritário vigente no país, por denúncia vingativa de uns pouquíssimos colegas. De tal modo ela insistia em levar adiante sua obstinação de denunciar minha falta, que o diretor decidiu, ele mesmo, dar as informações necessárias e enviar o expediente à Reitoria, acolhendo o entendimento do Departamento, o que foi aceito.

Agora abordo o exercício da minha relativa liderança na Antropologia. Em larga medida tal liderança, como já indicado, teve origem em minha maior presença na Universidade, em relação a dos colegas. Também contribui para seu afloramento o desinteresse, por vezes, apatia, dos colegas para tratar de questões de cunho mais administrativo. E, tais questões, eram numerosas e relevantes. Entre os mais corriqueiros e formais estavam o vestibular, matrículas, transferências, reconhecimento de créditos de alunos, horários das aulas. Os eventuais e mais informais, incluíam coisas como, indicar livros e revistas para aquisição pela biblioteca, em geral a toque de caixa, para aproveitar uma dada verba, antes que ela fosse recolhida por falta de uso; postular conserto ou disponibilidade de material de aulas ou pesquisa: projetor de diapositivo, retroprojetor (que exigiam sala escura), gravador, papéis para provas, mimeógrafo (não havia ainda o xerox); acompanhar fichamento de livros na biblioteca; sociabilidade com visitantes, comparecimento a eventos; representar a Faculdade, o Departamento ou a disciplina, em situações diversas. Tais coisas só deixam de ter importância para aqueles que sabem que alguém as assumirá, em seu lugar.

A intensidade de meu envolvimento com tudo isto fez com que a fora as questões formalmente de responsabilidade do catedrático, na prática eu respondia pela disciplina na maioria das questões. Às minhas atividades extraclasse acrescento ainda a de secretário do Colegiado do Departamento de Ciências Sociais, no período 1968-1972. De tudo isto resultou benefícios para mim e para a disciplina.

Como bem cedo passei a conhecer a máquina administrativa e seus macetes, pude operá-la com razoável sucesso. No que respeita as listas para 
aquisição de livros pela biblioteca, descobri que a massa dos professores da área das Ciências Humanas era completamente desinteressada, por creditar que o propósito não seria atingido. Assim, os poucos que atendiam a solicitação, eu entre eles, tinham suas chances de sucesso redobradas. Evidente que as minhas listas continham as sugestões dos colegas da disciplina.

Como a biblioteca também podia solicitar a importação livros, minhas listas contavam com tal possibilidade. Por conta da importação, para a biblioteca e para mim, tornei-me o principal cliente da Livraria Kosmos, que existia na rua da Praia, até há bem pouco tempo.

Em complementação à compra de livros pela biblioteca, também acompanhava de perto a catalogação, para poder utilizá-los logo que necessário. Contando com a extremada boa vontade das bibliotecárias não só conseguia que livros de meu imediato interesse fossem catalogados com extrema rapidez, como obtive permissão para retirá-los mesmo antes que isso se desse.

Ainda no que respeita à catalogação também obtive sucesso na superação de um problema de relativa importância prática e simbólica: fazer com que todos os livros de Antropologia que fossem adquiridos, antes com frequência catalogados em Sociologia, passassem a ser catalogados em Antropologia e, por consequência, colocados em suas respectivas estantes. Falei em importância simbólica porque, no quadro de socialismo triunfante e de revoluções mundo afora, a hegemonia da Sociologia e Política na área das ciências sociais aparecia como coisa natural. Sobrava pouco espaço para a Antropologia, pouco preocupada em estudar os conflitos pela manutenção/conquista do poder econômico/político.

No caso específico da UFRGS, embora as relações amistosas e, mesmo de intensa camaradagem, entre os professores das três áreas, era perceptível a desconsideração acadêmica dispensada à Antropologia por sociólogos e cientistas políticos. Por extensão, a mesma coisa se passava entre os alunos, em especial no curso de Ciências Sociais. Lembro-me que, bem compreendendo a situação, o professor Schmitz dizia algo muito próximo de "é preciso dar duro, vamos trabalhar bem para nos descobrirem e nos respeitarem”. Não julgo exagero dizer que ele acertou na mosca.

Exemplo emblemático de tal desconsideração foi um episódio ocorrido em reunião do grupo de trabalho designado pelo Colegiado do Departamento para apresentar propostas para uma profunda alteração no currículo do curso de Ciências Sociais. Os representantes da Sociologia e da Política se manifestaram contrários ao oferecimento, ainda que como opcionais, de 
disciplinas de antropologia, com articulação curricular equivalentes a disciplinas a serem oferecidas por aquelas áreas, como obrigatórias. A situação foi revertida com o apoio do professor José Carlos Grijó, representante da Estatística. Sua forte manifestação foi fundamental para que se estabelecesse a plena simetria curricular entre as três áreas. Por sua vez, tal reformulação curricular se deu no quadro de uma ampla reforma universitária. Com ela o sistema de cátedras foi extinto e substituído pelo sistema departamental. Em decorrência todos os docentes passaram a ter uma só vinculação departamental. No caso da Antropologia, juntamente com Ciência Política e Sociologia, a vinculação se deu com o Departamento de Ciências Sociais. Pelo novo sistema, os Departamentos passaram a ter importantes responsabilidade administrativas e pedagógicas, exercidas através de seus colegiados.

Numa segunda etapa, em 1970, a mesma reforma extinguindo a Faculdade de Filosofia, substituiu-a por vários institutos. Entre eles o de Filosofia e Ciências Humanas, integrado pelos Departamentos de Ciências Sociais, Filosofia e História.

No mesmo ano as responsabilidades pedagógicas dos Departamentos foram assumidas pelas Comissões de Carreiras. Por sinal, integrei, quando de sua instalação e, por dois anos, a de Filosofia e Ciências Humanas. Mais tarde também integrei as de Letras e Educação.

Como membro do colegiado departamental, por período total não inferior a vinte anos, também fui seu secretário, como já disse. Por conta disto, tinha como atribuição formal mais relevante, fazer as atas de suas reuniões, via de regra, semanais. De modo informal, porém com regularidade, também secretariava o próprio Departamento e assessorava substantivamente seu Chefe. Tais atividades eram em geral compartilhadas com outros colegas mas, sobretudo com, com os professores João Guilherme Correa de Souza, da Sociologia, e José Antonio Giusti Tavares, da Ciência Política. Nos primeiros tempos o Departamento não dispunha de funcionários.

A respeito de reuniões do Colegiado do Departamento e de suas respectivas atas julgo oportuno dois registros.

O primeiro é que para bem ordenar as reuniões (por vezes tensas e com suscetibilidades postas em cena), foi elaborado um Regimento. Um dos seus dispositivos determinava que as declarações de voto só teriam registro em ata se apresentadas por escrito, até o final da reunião em que eram formuladas. Este mecanismo se impunha e foi duplamente eficaz. As declarações de votos que eram abundantes, desde a implantação do Regimento se reduziram a um mínimo. Em consequência, as reuniões passaram a se desenvolverem 
ambiente harmônico e se tornaram produtivas. Antes se passava o oposto, com os autores das declarações de voto alegando, quase que por princípio, que o registro em ata, de suas manifestações, não tinha sido fiel ao espírito e/ou a letra com que foram expressos. Refletindo sobre a questão agora, penso que tais contratempos se devessem, sobretudo, a preocupação de certos colegas em firmar prestígio num organismo em processo de institucionalização.

O segundo registro é que, não sendo minha letra das mais legíveis, ao contrário do que se passa com a de minha esposa, Carmem Maria Ulrich Teixeira, apelava para sua boa vontade, para passar meus rascunhos para o livro de atas. Professora de português, competente e cuidadosa, ela ainda os burilava.

Todas as atas assinadas por mim, neste livro, foram transcritas por ela. Em muitas outras oportunidades ela também emprestou sua colaboração à Antropologia. Aúltima foi participar da revisão de Horizontes Antropológicos 5. Tudo graciosamente, como parece ser próprio de professor. De tanto conviver com a Antropologia, inclusive me acompanhando em eventos importantes da área (como reuniões da ANPOCS e ABA), além de formar consideráveis relações nos círculos antropológicos, pelos conhecimentos desenvolvidos ela pode ser considerada como para-antropóloga.

No final de 1969/início de 1970, como parte do processo geral de expansão universitária no país, o Departamento' de Ciências Sociais foi contemplado com quatro vagas para professor. Pela redistribuição interna foram atribuídas duas vagas à Sociologia, uma a Antropologia e uma à Ciência Política. Feita a divisão das vagas, numa próxima reunião cada área deveria indicar seus candidatos. Pelo lado da Antropologia pensei em dois nomes, que submeti à apreciação dos três outros colegas da disciplina. Todos, além de concordarem com os nomes apresentados, me delegaram a tarefa de encontrar alguém para preencher a vaga, em caso de impedimento dos indicados. Logo no início da reunião para a indicação dos nomes ficou decidido que a Antropologia se manifestaria por último. Fiquei preocupadíssimo com a decisão. Minha preocupação era legítima e de ordem prática. Isto porque, além de estar de fato fixado num só nome, na minha avaliação, ele também poderia ser indicado pelas outras áreas. Como tal não se deu, pude fazê-lo, nervoso, porém contente: apresentei o nome de Ruben George Oliven. Feita a apresentação, o responsável pela indicação dos nomes para a Sociologia, recordo bem, lamentou-se por não tê-lo considerado entre suas alternativas.

Informando Ruben da aceitação de seu nome também lhe disse, brincando, que para não ficar me devendo favor, ele deveria me dar uma 
garrafa de uísque. Ganhei uma de Chivas. É hora de dizer que nunca o fato de tê-lo indicado foi entendido por mim como contemplando um mínimo de favor. Indiquei-o, unicamente, por entender ser ele o melhor, em todo o meu horizonte de possibilidades. Meus juízos sobre ele resultaram de ponderações sobre seu desempenho acadêmico e modos de ser, como meu aluno no curso de Ciências Sociais. Com tais considerações também estou dizendo que a companhia dos bons não me intimida, muito ao contrário.

Admitido em 1970, Ruben foi o primeiro professor da Antropologia proveniente de um curso de Ciências Sociais e também o mais jovem, com vinte e quatro anos. Por conta disto e, por bom tempo, passei a tratá-lo de Benjamim, no que fui seguido por alguns colegas de Departamento.

Afável, dedicado ao trabalho e competente, desde o princípio integrou-se com facilidade ao grupo da Antropologia, relacionando-se harmoniosamente com todos os professores do Departamento. Todavia, comigo se estabeleceu um relacionamento mais intenso, consolidado a cada dia. Como causa e efeito, compartilhando as mesmas salas de trabalho desde 1972. Ao longo desde tempo construímos um relacionamento fraterno, marcado pela cooperação, respeito, amizade e afetividade.

Nossa primeira sala, muito apropriadamente chamado por nós de cubículo, pois não teria mais do que $6 \mathrm{~m}^{2}$, e com a porta como única abertura, dando para um corredor, resultou da divisão, em quatro partes, de uma outra sala, nos foi concedida pelo Departamento, em 1972. Em espaço igual e contíguo funcionavam a chefia e a secretaria do Departamento. Isto serve como indicador preciso de nossas carências gerais.

Ainda que exíguo, nosso cubículo representou uma conquista, pessoal e institucional. Para quem só dispunha de uma pequena gaveta para guardar algum material, na sala de professores, foi um grande salto passar a dispor de uma sala. Ela também se constituiu em conquista institucional porque, desde a década de 50, este foi também o primeiro espaço atribuído à Antropologia. Até então seu único espaço era uma sala contígua ao cubículo, usada para guardar e/ou expor materiais indígenas e aparelhos para o estudo de Antropologia Física. Os outros três colegas da área também costumavam utilizar esta sala, especialmente o professor Brochado.

No cubículo, não sei como, conseguimos colocar três escrivaninhas, três cadeiras, um armário metálico e, grande conquista, uma máquina de escrever de carro grande. O espaço para circulação girava em torno de $1 \mathrm{~m}^{2}$. Aí, por vezes, e também não sei como, chegávamos a cinco pessoas, nós dois e alunos bolsistas. 
O armário, ainda em uso, e a máquina, aposentada, são peças importantes do acervo do, digamos assim, museu funcional da Antropologia, estão em nossa sala.

Por circunstâncias muito especiais, em 1971 ocorreu um fato de primeira importância para todo o Departamento de Ciências Sociais. O relacionamento acadêmico entre o Chefe do Departamento, professor Luiz Alberto Cibils e o sociólogo Achim Schrader, da Universidade de Münster, Alemanha, e que realizava pesquisas no Brasil, evoluiu para um relacionamento bem pessoal: tornaram-se compadres. Cibils batizou um filho de Schrader. A partir daí criaram-se as condições que conduziram a um convênio entre o Departamento e a Ökumenis Studienwerkches, instituição vinculada à Igreja Evangélica de Confissão Luterana, que fornecia bolsas de estudos para alunos do chamado Terceiro Mundo.

Se bem me lembro, foram atendidas todas as solicitações do Departamento, em torno de dez, contemplando as suas três áreas. Como na Antropologia só Ruben e eu manifestamos interesse, postulei e obtive, duas bolsas para nós.

O resultado foi altamente positivo. O Departamento que não contava como nenhum pós-graduado em stricto sensu pôde incorporar em cerca de cinco anos, dois mestres e cinco doutores.

Quando da implantação em 1972, de um Primeiro Ciclo, comum a todos os alunos que ingressassem na UFRGS a partir de então, o relativo prestigio da Antropologia que já se manifestava na época, se materializou. Os conteúdos humanísticos deste Primeiro Ciclo seriam desenvolvidos sob sua égide, através de uma disciplina chamada Introdução ao Estudo do Homem e coordenada por mim. Sei de boa fonte, que tais decisões, tomadas fora do Departamento, provocaram mal-estar na área de Sociologia, que sentiu-se desprestigiada.

Uma das minhas primeiras providências foi montaruma comissão assessora, que foi composta pelos professores: Lúcia Gaspari, da Educação, Ruben Oliven, da Antropologia, Earle Macarthy Moreira, da História, e Francisco Ferraz, da Ciência Política. Os dois últimos chegaram a Reitor, na década de 80.

A implantação do Primeiro Ciclo se deu de forma muito tumultuada. A simples escolha dos coordenadores das seis disciplinas que o integravam, a definição de seus conteúdos e montagem dos respectivos corpos docentes, por si só, ilustram bem a situação.

Numa espécie de parênteses registro como se deu a definição dos conteúdos de introdução ao estudo do homem. Sua comissão coordenadora, exceto a professora Lúcia, reuniu-se num final de tarde num bar freqüentado por estudantes, próximo à Universidade e, tomando Malzibier, definiu-os em meia hora. 
Tudo se deu entre janeiro e princípios de abril, com o início das aulas. A tais dificuldades somava-se mais um complicador, intrínseco a própria concepção do Primeiro Ciclo: representava uma espécie de novo vestibular para metade dos alunos. Enquanto 50\% dos alunos melhores classificados no exame vestibular tinham asseguradas suas vagas nos cursos escolhidos, a garantia de vagas para os restantes $50 \%$, nos cursos pelos quais optaram no vestibular, dependia do desempenho no Primeiro Ciclo. Pela permanente tensão provocada por tal norma, ela foi suprimida quando da transformação do Primeiro Ciclo em Ciclo Básico, em 1974. Esvaziado de sua importância anterior foi extinto posteriormente. Como parte daquela transformação e reação da área de Sociologia, a disciplina de Introdução ao Estudo do Homem foi substituída pela de Introdução à Sociologia.

Apesar de tudo, Introdução ao Estudo do Homem - diga-se de passagem, bem trabalhada, resultou em benefícios para a Antropologia, para Ruben e para mim. Para a Antropologia, porque tornou-se favoravelmente mais conhecida. Para nós por uma melhoria salarial muito significativa. Nosso regime de trabalho que havia passado de doze horas semanais para vinte e quatro horas em 1971, agora passava para quarenta horas. Isto ganha maior relevância porque, até então, tal regime de trabalho e de dedicação exclusiva, eram raridades na UFRGS.

No que refere-se a mim, também registro que, para poder atender as atribuições inerentes àquela coordenação, professor que era do magistério estadual, fui cedido pelo Governo do Estado para a Universidade, situação que perdurou até minha aposentadoria naquele cargo, facilitando enormemente minha vida universitária, incluindo a realização do mestrado.

Com bolsa da Ökumenis Studienwerkches, realizei o curso de Mestrado em Antropologia Social, na Universidade Estadual de Campinas - UNICAMP, no período 1973-1976. Em tal período permaneci afastado da UFRGS somente em 1973, dedicado a obtenção dos créditos e o primeiro semestre de 1974, dedicado à pesquisa de campo. Orientado pelo professor Luiz Mott, que realmente me ajudou, fiz uma dissertação intitulada $O$ Bordão do Pobre: um estudo sobre o gado como estratégia econômica para uma população minifundiária do Rio Grande do Sul.

Com a obtenção do título de mestre, tornei-me o primeiro pós-graduado, stricto sensu, da Antropologia da UFRGS. Por isto e, sobretudo, porque na época o título de mestre ainda tinha considerável expressão, fui objeto de homenagem do Instituto de Filosofia e Ciências Humanas, promovida por seu Diretor, professor Dante de Laytano, em seu gabinete. A foto a seguir apresenta um registro do evento. 


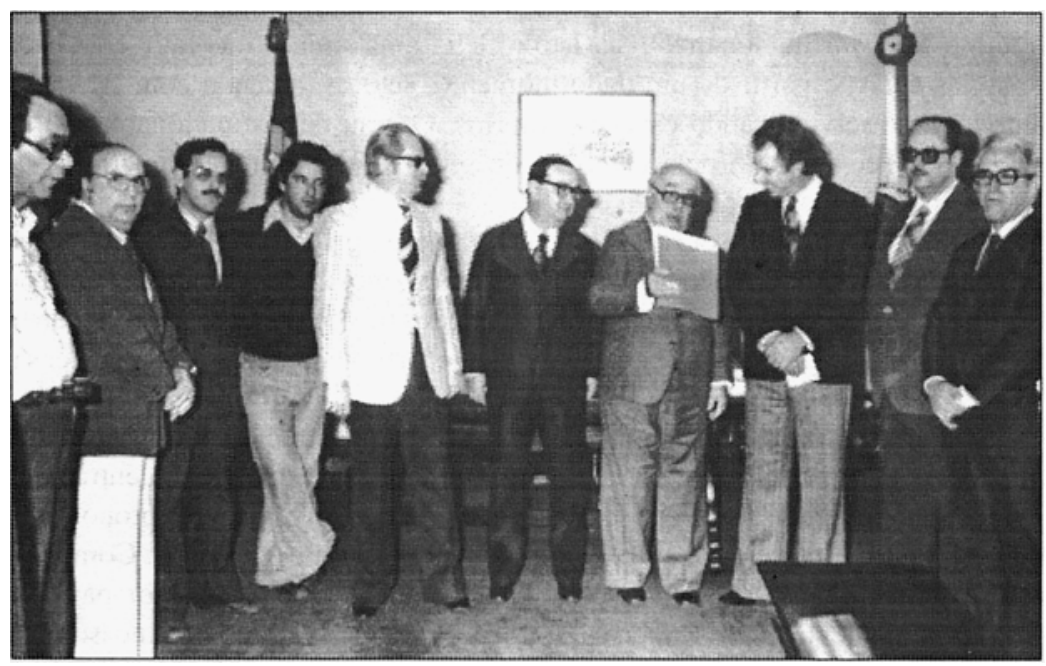

Da esquerda para direita: Raphael Copstein, Plínio Russomano, Roberto Fachin, Francisco Ferraz*, Luiz Carlos Hotmann, Hotelo Laurent, Dante de Laitano, Sérgio Alves Teixeira, Earle Macarthy Moreira* e Iuiskon Dick*.

* Posteriormente foram reitores da UFRGS

A propósito do professor Dante de Laytano, é oportuno registrar que dentre seus pioneirismos dois dizem respeito a interesses da Antropologia: estudos sobre o negro e o folclore no Rio Grande do Sul.

Também em 1976 os professores Pedro Ignácio Schmitz e Arthur Rambo obtiveram os títulos de Doutor e Livre Docente, com exame de Livre Docência na Pontifícia Universidade Católica do Rio Grande do Sul - PUCRGS.

Uma outra conquista de título para a Antropologia foi o Doutorado de Ruben Oliven, na Universidade de Londres, realizado no período 1974-1977, também com bolsa da Ökumenis Studienwerkches. Com seu retorno em 1978, ele tornou-se o primeiro doutor stricto sensu da Antropologia da UFRGS.

A obtenção destes quatro títulos em período tão curto não se deu por questões de mera coincidência, mas como parte dos esforços do Setor de Antropologia para se qualificar.

Esclareço que lá pelo início dos anos 70, como parte da estratégia para marcar uma identidade própria da área de Antropologia, nós, seus integrantes, passamos a referi-la como Setor de Antropologia. Como em pouco tempo a mesma forma de identificação foi adotada pelas áreas de Ciência Política e 
de Sociologia, o termo setor institucionalizou-se. Isto refletia uma situação de fato, com cada uma das áreas, a partir de um dado momento, setores, atuando com crescente autonomia e reivindicando espaços próprios. O grau de institucionalização de setor pode ser avaliado pela extensão de seu uso às instâncias superiores da Universidade e mesmo para fora dela.

Em 1972, o professor Francisco Ferraz, mestre pela Universidade Princeton e integrante do Setor de Ciência Política liderou um movimento para a implantação de um curso de mestrado, com a participação dos três setores que compunham o Departamento de Ciências Sociais. Assim esperava reunir recursos para compensar nossa fragilidade generalizada.

Coube ao professor Schmitz apresentar a proposta da Antropologia para nossa eventual participação no curso em questão. Por estar muito centrada na arqueologia indígena sua proposta foi julgada incompatível com as proposições dos dois outros setores, por uma comissão de consultores da Capes. Como tais setores entenderam que a apresentação de uma nova proposta por parte da Antropologia, tentada por Ruben e por mim, complicaria o processo, nosso setor ficou de fora. O fato, logo se viu, foi benéfico para a Antropologia: ao mostrar com crueza toda a nossa fragilidade estimulou esforços para sua superação.

Em 1973, somando forças e compensando deficiências, os outros setores instalaram um curso de Mestrado em Política e Sociologia. Da Antropologia só participou Ruben Oliven, já na primeira turma, e que havia concluído o mestrado em Planejamento Urbano, na UFRGS, no mesmo ano.

Com minha ida para Campinas, Ruben que me substituíra no Colegiado do Departamento, com disposição de lutar pelo crescimento do Setor de Antropologia e mostrando liderança, organizou um curso de Especialização em Antropologia, desenvolvido em 1974. Este curso marca o início de pós-graduação em Antropologia na UFRGS, em lato sensu. Seu corpo docente foi integrado por Peter Fry, da UNICAMP, Sílvio Coelho dos Santos, da Universidade Federal de Santa Catarina, uma doutoranda da Universidade Cornell, Estados Unidos, que realizava pesquisas no Brasil, Pedro Ignácio Schmitz e Ruben Oliven, representantes da UFRGS.

O mesmo ano também registra dois outros marcos na docência da Antropologia: o ingresso da primeira mulher. Trata-se de Aimara Stefani Célia, oriunda do curso de Ciências Sociais, cuja a admissão, por seleção pública, se deu pela primeira vez. Demitindo-se em 1975, para casar, ela foi o primeiro docente da Antropologia a se afastar em definitivo.

Em 1975, dando continuidade ao empenho da Antropologia em 
desenvolver competência na pós-graduação, organizei e coordenei nosso II curso de Especialização em Antropologia Social. Este curso como se deu com seu antecessor, também contou com a colaboração de professores externos à UFRGS. Eu fui responsável por uma disciplina intitulada Normalidade e Desvio Social.

Com esta disciplina e com uma outra para uma turma avançada do curso de Ciências Sociais, voltada para o estudo dos ritos, eu, que como disse, quando falei de meu curso sobre a África, me aproximava meio sem saber da Antropologia Social Inglesa, agora, sabendo, me oriento por suas maneiras de compreender a vida sócio-cultural. E não poderia ser diferente, afinal era esta a orientação teoria que predominava na Antropologia em Campinas, o que também era natural que assim fosse. Dentre suas figuras mais exponenciais estavam Peter Fry, Antônio Augusto Arantes e Verena Stolcke, que foram meus professores e estudaram na Inglaterra.

Lembro que no curso sobre rituais trabalhei, além de com Les rites de passage, de Arnold Van Gennep, com o Proceso ritual, de Turner, publicado em português no ano anterior e com Purity and danger, de Mary Douglas, que só viria a ser publicado em português no ano seguinte. Uma conjugação de fatores, que incluía uma turma de poucos e brilhantes alunos, fez com que esta fosse uma experiência enriquecedora e agradável. Até hoje lembro de alguns deste alunos, entre eles Marlene Almeida, que construiu uma destacada carreira acadêmica, incluindo doutorado e chegando a professora concursada de Sociologia na UFRGS. Tal experiência seguramente contribuiu para que o estudo dos ritos viesse a ser uma das áreas de meu maior interesse.

Creio não violar os fatos se disser que 1975, com estas experiências, pode ser pensado como um marco importante, na UFRGS, na aplicação da maneira de compreender proposta pela Antropologia Social Inglesa. Com isto não estou dizendo que ela tenha banido outros modos de perceber o social. Como é próprio da Antropologia, também na UFRGS a convivência de muitas maneiras de abordar o social é entendida como enriquecedora de sua compreensão.

Em 1977 com a mudança do Instituto de Filosofia e Ciências Humanas para o Campus do Vale, e sua instalação num novo e amplo prédio, o Setor de Antropologia passou a dispor desde então de espaços para acomodar adequadamente, não só os sete docentes que o integravam no momento, como todos os que foram incorporados depois. Eu passei a ocupar uma sala, a ser compartilhada com Ruben, quando de seu retorno, no ano seguinte.

Por conta de meu prestígio, combinado com as condições favoráveis do momento, a direção do Instituto entendeu de acarpetar minha sala. Como eu era 
o único professor a dispor de sala de trabalho assim equipada, para minimizar possíveis suscetibilidades, o fato foi justificado pela minha condição de coordenador de um curso de Especialização em Sociedade, Cultura e Política na América Latina. Este curso, com conteúdos de Antropologia, História, Política e Sociologia, foi oferecido durante dez anos, com oito edições em instituições do interior do Estado e seis na UFRGS.

O próximo integrante do Setor de Antropologia foi Maria Noemi de Castilhos Brito, formada em História e com especialização em Antropologia, pela UFRGS. Técnica em Assuntos Educacionais da Universidade, por minha indicação ela assumiu como professora horista, em 1975. Pouco depois gestionei para que parte de seu tempo como funcionária fosse exercido com docência no Setor. Em 78, através de novas gestões, consegui que ela fosse lotada no Departamento de Ciências Sociais, integrando o Setor de Antropologia. Ela foi seu primeiro docente com pós-graduação quando de seu ingresso.

Após fazer mestrado na UNICAMP, ela fazia doutorado na Universidade de São Paulo - USP, quando faleceu em 1996. Professora e pesquisadora competente e entusiasmada, amiga leal e afetuosa, sua ausência entristeceu seus colegas e desfalcou a Antropologia. Pensando nela, lembrei agora de seu modo muito peculiar de mostrar toda sua disposição para fazer algo que the era solicitado ou dizer que não se sentia ofendida, exclamado "imagina".

Homenageando-a, Horizontes Antropológicos n.4, publicou como tributo de seus colegas à sua memória, um registro de sua trajetória acadêmica, elaborado por Claudia Fonseca e o Colegiado do Departamento de Antropologia estabeleceu o Prêmio Maria Noemi Castilhos Brito. Este prêmio será atribuído, a partir do segundo semestre de 1997, à melhor monografia de Antropologia, na conclusão do curso de graduação em Ciências Sociais.

Em 1978 o Setor de Antropologia ao incorporar a professora Claudia Lee Williams Fonseca, passa a contar com seu primeiro estrangeiro, de nacionalidade norte-americana, que também foi seu primeiro integrante a ter pós-graduação em Antropologia, stricto sensu, quando do ingresso: mestrado em Estudos Orientais, na Universidade de Kansas, Estados Unidos. A tal título ela agregou Doutorado de Terceiro Ciclo, na École de Hautes Études en Sciences Sociales, em 1981 e Doutorado de Estado, na Universidade de Paris X/Nanterre, em 1993, ambos na França.

O processo de admissão de Claudia merece registro, por sua peculiaridade. Em 1977, casada com um brasileiro e com intenção de se radicar no Brasil, enviou seu currículo para o Departamento de Ciências Sociais, com vistas a 
sua possível contratação. Lembro bem que suas vivências antropológicas no Alto Volta (atual Burkina Faso) e em Taiwan, despertaram atenção especial. O chefe do Departamento, professor Roberto Fachin, do Setor de Ciência Política, ouvido o Setor de Antropologia, empenhou-se intensamente em conseguir sua contratação. Tudo se passou rápido e bem. Em maio de 1978, recebi seu telefonema, já de Porto Alegre, e num português (sem jogo de palavras) claudicante, dando conta de sua chegada. Nossas necessidades, sua competência e disposição para o trabalho, a par de seu informalismo espontâneo e sedutor, fizeram com que sua incorporação à rotina do Setor fosse imediata e fácil. Suas tarefas docentes, já em seu primeiro ano entre nós, incluíram aulas na graduação e no III curso de Especialização em Antropologia, também organizado e coordenado por mim. Com este curso encerra-se a primeira fase de pós-graduação em Antropologia na UFRGS, em lato sensu.

Com a incorporação de Claudia e a realização deste curso julgamos atendidas as duas condições básicas que faltavam para a implantação de um curso de mestrado em Antropologia Social na UFRGS. Tais condições eram: corpo docente qualificado e experiência em pós-graduação. As outras condições, já satisfeitas, diziam respeito a coisas de infra-estrutura, como biblioteca, espaço físico, equipamentos e de oportunidade, como demanda potencial.

No que respeita a qualificação do corpo docente é imperioso dizer que todos os que detinham alguma responsabilidade no processo, reconheciam que ela se situava no limite inferior da escala. E não poderia ser outro o entendimento, pois éramos: dois livres docentes - Pedro Ignácio Schmitz e Arthur Rambo; um doutor - Ruben Oliven; dois mestres - Claudia Fonseca e Sérgio Alves Teixeira; e um doutorando - José Brochado. Na ocasião, só o último não foi proposto como orientador, o que se deu mais tarde, após concluir seu curso em 1983, na Universidade Illinois/Urbana, nos Estados Unidos. Portanto, a disposição de implantar um curso de mestrado contanto com esta massa crítica, continha lá seus componentes de temeridade.

A qualidade da tese de Brochado pode ser avaliada por manifestação de seu orientador, em apoio ao pedido de uma pequena prorrogação de prazo, para a conclusão de seu doutorado, requerida por seu orientando ao Departamento de Ciências Sociais. Disse ele que a partir da tese desenvolvida por seu orientando, os estudos de populações indígenas da América do Sul, nos aspectos por ele abordados, teriam um novo divisor: antes e depois do trabalho de Brochado.

O projeto de nosso mestrado, orientado para as sociedades complexas, apresentava um sistema curricular que compatibilizava a preocupação com 
a abordagem de um amplo espectro da vida sócio-cultural com os interesses dos professores e alunos. Tal se dava, para os primeiros, pela indicação das disciplinas pelas quais se responsabilizavam; para os segundos, pelas possibilidades de opção entre as disciplinas oferecidas. Apesar do reduzido número de professores, desde o princípio os alunos dispunham de efetiva possibilidade de opção. Tal se dava não só pela oferta de créditos, a cada semestre, acima do mínimo exigido, como também porque o exercício da opção era institucionalmente estimulado, pois só duas disciplinas tinham créditos obrigatórios: Teorias Antropológicas e Métodos e Técnicas de Pesquisa. No meu caso, assumi a responsabilidade por três disciplinas: Antropologia Econômica; Normalidade e Desvio Social e Símbolos, Rituais e Ideologias.

Apesar de nossas carências o projeto foi levado adiante e aprovado. Encaminhado à apreciação da Câmara de Pós-Graduação e Pesquisa da Universidade no primeiro semestre de 1979 foi por ela aprovado ainda no seu transcurso.

Sua aprovação por aquela Câmara veio acompanhada da determinação de sua inclusão, como uma nova área, no curso de mestrado em Política e Sociologia, em funcionamento desde 1973, que passou a chamar-se Curso de Pós-Graduação em Antropologia, Política e Sociologia. Em decorrência Ruben e eu fomos eleitos para integrar sua Comissão Coordenadora, que contava também com dois representantes de cada uma das outras áreas. Inicia-se, assim, a segunda fase da pós-graduação em Antropologia na UFRGS, agora em stricto sensu. Julgo oportuno destacar que na mesma época, inserido no contexto favorável ao desenvolvimento da pós-graduação no Brasil, outros grupos desenvolviam esforços semelhantes para implantar novos cursos de pós-graduação em antropologia no país. Refiro-me especialmente à Universidade Federal de Santa Catarina e à Universidade Federal de Pernambuco, que lograram sucesso. Os novos cursos vieram se somar aos cursos mais antigos localizados no clássico eixo Rio-São Paulo-Brasília.

Com base na mesma resolução que também estabelecia que a Coordenação do novo Curso caberia a cada área, em sistema de rodízio, Ruben foi o Coordenador no período 81/83.

Cumpridas as formalidades para a implantação do curso, uma das primeiras providências foi abrir o processo de seleção para compor sua primeira turma, que foi integrada por sete alunos. Julgo oportuno registrar, que não obstante a pouca divulgação de nosso curso, sua primeira turma já contou com um aluno de outro Estado. Foi Antonio Maria de Souza Santos, pesquisador do Museu Emílio Goeldi, de Belém, Pará. Uma peculiaridade associada 
à seleção deste candidato é que ele foi entrevistado na sede de sua instituição, por Ruben e por mim, com um intervalo de alguns dias. Coincidentemente, aproveitando nossa ida para uma reunião da SBPC em Fortaleza, resolvemos, com roteiros distintos, dar uma esticada pela Região Norte, incluindo uma visita a Belém. A decisão de entrevistar o candidato aí foi uma camaradagem nossa a seu bolso. Praticamente todas as outras turmas sempre tiveram alunos de outros Estados. Mais tarde apareceram também alunos vindos do exterior.

A aula inaugural do mestrado, em agosto de 1979, foi proferida pelo professor Octávio Velho, do Museu Nacional-UFRJ. Foi uma excelente palestra, seguida de agradável coquetel, tudo no pátio coberto do prédio atualmente ocupado pelo Instituto de Letras, cujo andar superior, à época, era ocupado pelo Instituto de Filosofia e Ciências Humanas.

O convite ao professor Octávio Velho para proferir a aula inaugural, além da garantia de destaque para evento tão relevante também indicava nossa disposição de buscar o diálogo intenso com outros centros avançados de investigação antropológica, o que vem se dando ao longo do tempo.

Com tal preocupação, passamos a participar de reuniões científicas de cunho nacional, como as do Centro de Estudos Rurais e Urbanos - CERU -; da Associação Brasileira de Antropologia - ABA -; da Associação Nacional de Pós-Graduação e Pesquisa em Ciências Sociais - ANPOCS - e Sociedade Brasileira para o Progresso da Ciência - SBPC- criando condições para que nossos alunos também se fizessem presentes. A propósito das reuniões do CERU, me permito referir um fato que me deu grande satisfação e que deve ter ocorrido na reunião de 82 ou 83, a que compareci acompanhado de três orientandos meus. Entusiasmada pelas consistentes comunicações que eles fizeram, centradas em suas respectivas dissertações ainda em andamento, a professora Maria Isaura de Queiroz, fundadora e expressão maior do CERU, declarou algo muito próximo de "a julgar pela amostra, a Antropologia da UFRGS está muito bem”.

A inclusão de um examinador de fora da UFRGS nas comissões examinadoras de dissertação, sistematicamente posta em prática, se mostrou instrumento de grande valia para aquele diálogo. Tanto mais que, como regra, o visitante também é solicitado a dar uma palestra e, eventualmente, discute projetos de alunos. Renomados antropólogos brasileiros e estrangeiros integraram tais comissões. Tudo isto em conformidade com a orientação posta em prática, desde o início de, sem desprezo pelo regional, voltarmo-nos para o mais geral As linhas de pesquisa desenvolvidas pelo Programa estão afim com esta orientação, quais sejam: 
Urbanização, Sociedade e Cultura no Brasil;

Cotidiano e Gênero;

Antropologia Indígena;

Religião, Identidade e Etnicidade;

Antropologia do Corpo e da Saúde;

Memória, Identidade Social e Sociabilidade;

Antropologia e Problemática Ambiental;

Antropologia Visual e da Imagem;

Etnomusicologia.

O primeiro examinador externo foi o professor Renato Ortiz, na ocasião vinculado à Universidade Federal de Minas Gerais. Ele, Ruben Oliven e eu, compusemos a comissão examinadora que examinou nossa primeira dissertação, em 1983, de Ondina Fachel Leal, intitulada A leitura social da novela das oito, orientada por Ruben Oliven. Ela foi também a primeira das nossas duas únicas dissertações examinadas por parecer. Na ocasião a autora já realizava doutorado na Universidade da California/Berkeley. Esta dissertação detém ainda outra primazia: com o mesmo título e pela Editora Vozes, 1986, foi a primeira das nossas seis dissertações publicadas. As outras cinco são:

As santas prostitutas: um estudo de devoção popular no Rio Grande do Sul, de Antonio Augusto Fagundes, orientada por Sérgio Alves Teixeira e defendida em 1984. Porto Alegre, Martins Livreiro, 1987.

Vila pobre vila - por uma antropologia médica, de Ernesto de Freitas, Xavier Filho, orientada por Sérgio Alves Teixeira e defendida em 1989. Porto Alegre, Sagra, 1991.

Demarcação de identidade em espaço coletivo - o shopping center Iguatemi em Porto Alegre, de Tânia Torres Rossari, orientada por Sérgio Alves Teixeira e defendida em 1990. De forma condensada, in PINTAUDI, Silvana M. e FRUGOLI JR., Heitor, Shopping Centers: espaço, cultura e modernidade nas cidades brasileiras. São Paulo, Unesp, 1992.

O batuque do Rio Grande do Sul, de Norton F. Corrêa, orientada por Ari Pedro Oro e defendida em 1990. Porto Alegre, Editora da Universidade-UFRGS, 1992.

Fotoetnografia: um estudo de Antropologia Visual, de Luiz Eduardo R. Achutti, orientada por Ondina Fachel Leal e defendida em 1996. Porto Alegre, Palmarinca/Tomo, 1997. 
Ao todo orientei onze dissertações, sendo nove na Antropologia; uma no Programa de Pós-Graduação em Planejamento Urbano e Regional e outra no Programa de Pós-Graduação em Administração, todas na UFRGS.

Para obedecer a uma certa cronologia abandono as questões relativas ao mestrado para registrar o ingresso, em 1979, como professora horista, de Daisy Barcellos. Com especialização em Antropologia, por ter feito nosso segundo curso, e professora de Introdução à Sociologia no Ciclo Básico, ela foi indicada por mim para me substituir no curso de Enfermagem. Numa espécie de parênteses registro que, interessado em promover a Antropologia, que Enfermagem e depois Odontologia, acolheram o oferecimento que lhes fiz de disciplinas de Antropologia, incluindo-as em seus currículos. Atualmente, na graduação, a Antropologia também integra os currículos dos cursos de Ciências Sociais, Geografia, História e Psicologia.

Conteúdos de Antropologia também integraram o currículo do Curso de Especialização em Odontologia Social/UFRGS, em duas edições nos anos 80. Nas duas oportunidades assumi a responsabilidade por seu estudo.

Quando do afastamento da professora Maria Noemi, em 1982, para fazer mestrado na UNICAMP, gestionei para que Daisy, substituindo-a, fosse transferida de Introdução à Sociologia para Antropologia, em caráter permanentemente. A partir daí ela também assume as aulas na Odontologia. Em decorrência de tais coisas, ela que dava andamento a uma dissertação de mestrado em Sociologia, no Programa de Pós-Graduação em Planejamento Urbano e Regional/UFRGS, conseguiu, através de um processo bastante complicado, reorientar sua dissertação para a área da Antropologia. Acabou por concluir o mestrado, em 1989, apresentando uma dissertação, por mim orientada, e intitulada Políticas de saúde mental e a organização do hospital público no Rio Grande do Sul. Assim, foi ela quem iniciou na UFRGS a pesquisa em Antropologia da Saúde.

Outro fato ligado ao ingresso da professora Daisy é que com ela encerram-se as admissões a partir de indicações feitas ao Departamento de Ciências Sociais. A partir daí, excetuando-se os professores visitantes e o caso muito particular do professor Robert Shirley, todas as admissões se deram por seleção no concurso público. A particularidade no caso do professor Shirley, norte-americano e professor da Universidade de Toronto, no Canadá, foi que, quando primeiro professor visitante no mestrado, foi efetivado por disposição legal em nível federal. Não obstante seu desejo de permanecer aqui, ao término de sua licença na Universidade de Toronto, ele se demitiu para retornar, porque as condições funcionais lá lhe eram mais favoráveis. Depois dele, muitos foram os professores visitantes no mestrado, 
de procedências e nacionalidades diversas. Um relevante instrumento para captar este tipo de colaboração foi o projeto a ser apresentado a seguir.

Em 1982 iniciou-se o processo que, a partir de 1985, institucionalizaria o mais importante mecanismo de intercâmbio do nosso mestrado com outras instituições. Refiro-me a nossa participação, através do Projeto 63/82 Antropologia Social-UFRGS, no Acordo CAPES/COFECUB, de cooperação franco-brasileira, cujos efeitos diretos deverão perdurar por muito tempo ainda.

Naquele ano, quando da visita do professor Claude Lefort, para avaliar os projetos dos mestrados da Filosofia e da Política no referido Acordo, o professor Ricardo Seitenfus, da Ciência Política, recente na Universidade e alheio a certas mesquinharias de ordem paroquial, que por vezes inibiam a cooperação mais fraterna nas Ciências Sociais, me instigou a também buscar a participação da Antropologia no mesmo Acordo.

Para facilitar as coisas, além de me convidar para um churrasco em sua residência, oferecido a Lefort, onde me apresentou a ele, também lhe falou de modo muito favorável, do trabalho desenvolvido pela Antropologia. Sem perda de tempo, Ruben e eu elaboramos um documento preliminar, sobre a Antropologia e suas pretensões no Acordo em questão, e que lhe apresentamos em reunião realizada dois ou três dias após aquele churrasco. Sua boa impressão, transmitida ao professor Seitenfus, nos garantiu o primeiro ponto: seu relatório seria favorável.

Embora não possa precisar como se deu, a verdade é que passei a ser o coordenador deste projeto embrionário. Quando veio a primeira manifestação da França, favorável e já com o projeto formalmente registrado, sob o número 63/82, exultante, enviei a resposta, que assinei como coordenador. Atendia, assim, a uma de suas solicitações, que era a indicação do coordenador brasileiro do projeto. A outra era a indicação do coordenador francês. Para tanto, foi acionada Claudia Fonseca, que se encontrava em Paris, fazendo doutorado, pelo que tinha condições favoráveis para encontrar alguém que assumisse aquele encargo. A resposta não demorou e sua escolha não poderia ter sido mais feliz. Tratava-se de Jacques Gutwirth, professor da Universidade de Paris V e Coordenador do Laboratório de Antropologia Urbana, do Centre National de la Recherche Scientifique. Foragido do nazismo, residiu seis anos no Rio de Janeiro, quando adolescente. Fluente em português, simpático, competente, prestigiado no meio universitário, trabalhador e verdadeiramente interessado no projeto, sua contribuição para seu sucesso foi maiúscula. A foto a seguir mostra o professor Gutwirth acompanhado de alguns integrantes do Programa por ocasião de uma de suas vindas a Porto Alegre. 


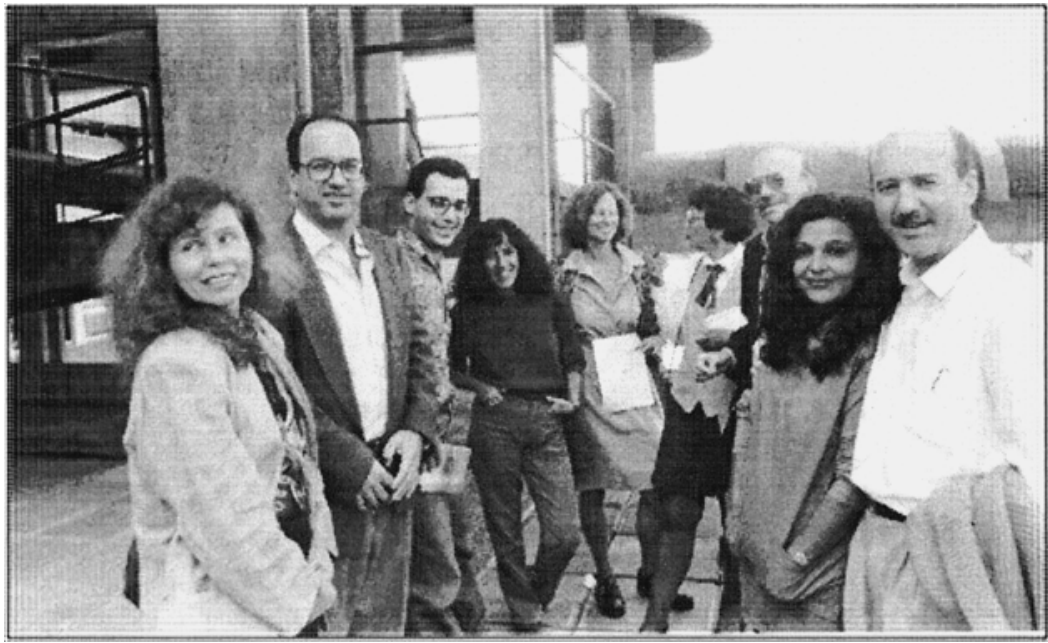

Da esquerda para a direita: Cornelia Eckert, Ruben Oliven, Bernardo Lewgoy, Daisy Barcellos, Claudia Fonseca, Maria Noemi Brito, Jacques Gutwirth, Ondina Leal, Ari Pedro Oro - 13/05/93 (foto: Luis E. R. Achutti).

Quando disse há pouco que os efeitos diretos do projeto para a Antropologia na UFRGS deverão perdurar por muito tempo ainda, não cometi qualquer exagero. Como se verá, pela utilização plena e competente de todos os mecanismos previstos no projeto para materializar o intercâmbio, os resultados para nós foram substantivos.

Em números, tais resultados se expressam por:

Nove estágios de pós-doutorado: Ari Pedro Oro, Arthur Rambo, Claudia Fonseca, Ondina Fachel Leal, Ruben Oliven e Sérgio Alves Teixeira. Duas observações: alguns cumpriram mais de um estágio e eu tinha status de doutor.

Um doutorado sanduíche: Maria Noemi Castilhos Brito.

Três doutoramentos: Cornelia Eckert, Maria Eunice de Souza Maciel e Jorge Pozzobon. As primeiras integravam o Setor de Antropologia quando saíram para o doutorado, ao contrário do último, que integrado diretamente ao mestrado como bolsa de recém doutor, demitiu-se poucos dias após sua admissão.

Onze missões de professores visitantes: Carmen Bernand (Universidade de Paris X); Claude Rivière e Jacques Gutwirth (ambos da Universidade de Paris V); Jean-Luc Jamard, Jean-Marie Gibbal, Jesus Garcia Ruiz e Margarita Xanthakou (os quatro do Centre National de la Recherche Scientifique). Rivière, Jamard e Xanthakou com uma missão e os demais com duas. 
Do projeto também resultou a incorporação à nossa biblioteca de um amplo e qualificado acervo de publicações francesas.

Um último resultado material deste intercâmbio e fora da programação original, foi a publicação do livro Brasil \& França: Ensaios de Antropologia Social. Porto Alegre, Editora da Universidade/UFRGS, 1992. Trata-se de um livro coletivo, organizado por Ari Pedro Oro e por mim, e com contribuição de onze das dezessete pessoas citadas, com direta participação no projeto. Todos os ensaios que compõem o livro resultaram de pesquisas desenvolvidas em função do projeto.

Assim como se deu com o professor Jacques Gutwirth que exerceu a coordenação pelo lado francês durante toda a vigência do projeto, na prática o mesmo se deu comigo, pelo lado brasileiro. Logo que passei a coordenação para o professor Ari Pedro Oro, em função de minha aposentadoria, o projeto não teve sua continuidade renovada. O motivo apresentado para tanto foi de que já não necessitávamos de tal apoio.

O ingresso no Setor de Antropologia das já referidas Ondina Fachel Leal, Cornelia Eckert e Maria Eunice de Souza Maciel, em 1986, representa dois marcos em sua história: primeiras admissões por concurso público e primeiras incorporações de mestres formados por nosso mestrado. A banca examinadora, presidida por mim, foi composta, também, por Ruben Oliven e Daisy Barcellos. Na oportunidade Ondina já cursava doutorado na Universidade da Califórinia/Berkeley, que concluiu em 1989.

A mesma banca também foi a responsável pelo segundo concurso, do qual resultou a admissão de Ari Pedro Oro e de Luiz Ricardo Centurião, em 1989. O primeiro, já nosso professor na ocasião com bolsa de recém doutor, titulado pela Universidade de Paris III (França), e o segundo com mestrado pela UFRGS.

A propósito de presidência de bancas de concursos registro que presidi as dos dois concursos para professor titular, para a Antropologia na UFRGS, realizados até a gora. A banca do primeiro, em 1984 contou também com a participação dos professores João Baptista Borges Pereira da USP e Sílvio Coelho dos Santos, da UFSC. A do segundo, em 1991, contou também com a participação desde e mais a do professor Roque Laraia, da UnB.

Esclareço que eu, como se deu Brasil afora, com numerosos outros professores de Universidades Federais, tornei-me "titular biônico”, em 1981, com base em dispositivo da Constituição de 1967. O mesmo se deu com o professor Arthur Rambo. Assim, junto com o professor Schimitz, a Antropologia tinha na época três representantes natos na Congregação do IFCH. Com as nossas 
aposentadorias (Schmitiz em 86, Rambo em 91 e eu em 92), e pelas promoções de Ruben Oliven, pelo primeiro concurso e de Claudia Fonseca e de Ondina Leal, pelo segundo, tal representação continua com a mesma expressão numérica.

Já que falei em IFCH, aproveito para registrar que fui seu Vice-Diretor, no período 81-84. Este foi o posto executivo mais elevado que ocupei na hierarquia da administração universitária. Todavia, mesmo tendo exercido a direção por longos períodos, minha atuação administrativa mais relevante se deu quando do exercício de função situada hierarquicamente mais abaixo. Refiro-me à Coordenação do Programa de Pós-Graduação em Antropologia Social, resultante da transformação do nosso antigo mestrado, em 1986. Exerci a Coordenação por dois períodos consecutivos, de sua implantação até 1990.

A transformação do mestrado em Antropologia, que integrava o antes referido Curso de Pós-Graduação em Antropologia, Política e Sociologia, em Programa independente, se deu como conseqüência de um processo natural de amadurecimento, vivenciado também por aquelas áreas. Bem cedo se percebendo que a autonomia possibilitaria que cada área atendesse melhor seus interesses, o processo se desenvolveu sem traumas e com relativa brevidade. Tanto mais que a autonomia formal consolidou uma situação de fato. Como a esta altura, a secretaria era o que havia realmente de comum, móveis, equipamentos e espaços foram equanimemente divididos entre as três áreas. As três funcionárias optaram a que Programa se vinculariam. Disso resultou que cada Programa ficou com uma secretária.

Na mesma época em que se deu a separação dos cursos de pós-graduação, e com a mesma motivação, em reunião do colegiado do Departamento de Ciências Sociais, apresentei, com registro em ata, e em nome do Setor de Antropologia, sua determinação de realizar as gestões necessárias para se transformar em Departamento de Antropologia. Pouco depois, os setores de Política e Sociologia também manifestaram a mesma disposição. Após muitas marchas e contramarchas, em 1993 foram criados os três departamentos. A professora Maria Noemi Castilhos Brito foi eleita Chefe do Departamento de Antropologia. Aposentada por motivo de doença, foi substituída pela professora Daisy Barcellos. Esta por sua vez, ao ser eleita Chefe do Departamento de Ciências Sociais em 1986, foi a única mulher e o único representante da Antropologia a ocupar tal cargo. Ela foi reconduzida para um novo mandato.

Volto agora a me ocupar do Programa de Pós-Graduação em Antropologia Social. Definido sua implantação pelas instâncias pertinentes da Universidade, o passo seguinte, já em seu âmbito interno, foi a eleição de sua Comissão 
Coordenadora, que foi composta por Claudia Fonseca, Ruben Oliven e por mim. Os dois por sua vez, me indicaram para Coordenador, o que foi referendado pelo Reitor.

Implantado o Programa, a preocupação da Comissão Coordenadora, foi a de elevar sua qualificação. Para tanto buscou-se reforçar a infra-estrutura, com destaque para a aquisição de material bibliográfico e equipamentos para a secretaria; estimular o desenvolvimento de projetos de pesquisas, que compreendia também a publicação de resultados; intensificar a participação/organização de fóruns científicos; incorporar novos doutores e, como meta que representasse o coroamento de tudo isto, obter o reconhecimento da CAPES. Com o respaldo financeiro da FINEP, CAPES, CNPq e FAPERGS (Fundação de Amparo a Pesquisa do Estado do Rio Grande do Sul), apoio do Acordo CAPES/ COFECUB, e com o trabalho de todo o pessoal da Antropologia, pertencente ao Programa e/ ou Setor, tudo foi conseguido. O relatório da comissão de avaliação da Capes, para o reconhecimento, integrada pela professora Guita Debert, da UNICAMP, e pelo professor Luiz Fernando Dias Duarte, do Museu Nacional/ UFRJ, foi motivo de justa satisfação para nós. Além de integralmente favorável, consagrava nossos esforços, se perguntado como um grupo tão pequeno pôde realizar obra tão avultada. O Programa de Antropologia, mesmo tendo origem mais recente do que seus dois co-irmãos foi o primeiro a ser reconhecido pela CAPES, o que se deu 87. Obtido o reconhecimento, ficou pairando no ar, como coisa natural, que nossa próxima meta seria a implantação do doutorado.

Para comemorar o reconhecimento Ruben e eu, acompanhados de nossas mulheres, jantamos em alto estilo num dos mais badalados restaurantes de Porto Alegre na época. Claudia Fonseca que também integrava a Comissão Coordenadora encontrava-se na França, na época função de seu doutorado.

Já que falei em jantar comemorativo aproveito para falar nas festas do Programa, corriqueiras desde o seu início. Nos primeiros tempos, organizadas pelos alunos, sempre na residência de algum deles, justificadamente eram referidas como Potlatch, não pelo esbanjamento de bens, mas pelo transbordamento de alegre convivência. Hoje ocorrem também em locais públicos, como em bares. Porém, mantendo a tradição do Potlatch, temos as festas na casa de Ondina Leal. Ela, sempre disposta, competente e generosa muitas vezes oferece a festa ou sua casa. Em algumas oportunidades como dever de ofício, para atender compromissos de sociabilidade com visitantes.

Falando em tais compromissos, lembrei que por costumarmos levar nossos visitantes no Restaurante Steinhause, na rua Paulino Teixeira, por 
vezes seus responsáveis nos brindavam com algum oferecimento. Aí fui homenageado, por colegas do IFCH, com um jantar, organizado por Maria Noemi, quando de minha aposentadoria.

Quando da recondução da Comissão Coordenadora para um novo mandato, declarei que como Coordenador, assumia o compromisso de me empenhar para a implantação do doutorado, se de fato este fosse o interesse do grupo.

Para todos nós, trabalhando com a dedicação de sempre e com publicações crescentes, embora quase não se falasse no tema, a questão do doutorado estava muito presente, como se verá.

Fiel a meu compromisso e bem avaliando as coisas, já para o final de meu mandato, em 1990, reuni todos os professores do Programa para que avaliássemos a disposição e conveniência da implantação do doutorado. Como imaginava, ou melhor tinha plena certeza, as respostas foram positivas. Em razão do que, na mesma reunião foi formada uma comissão integrada por Ari Pedro Oro, Cláudia Fonseca e Ondina Leal, para apresentarem uma proposta de currículo, para ser apreciada por todo o grupo, em reunião já marcada para daí a três semanas. Feito isto, já na semana seguinte, o projeto foi aprovado numa terceira reunião.

Bem historiando os fatos me imponho uma inconfidência, que embora já tenha falado, é a primeira vez que a registro por escrito. Como entendi que a proposta poderia ser prejudicada pelo tempo tão curto em que foi, de fato, definida e, com a plena aprovação dos colegas e, para os efeitos do processo, tal prazo foi ampliado. Para tanto, foram alteradas as datas das atas das reuniões em que a questão foi discutida e aprovada. Tais atas deveriam ser anexadas ao expediente com a proposta, a ser submetida à apreciação da Câmara de PósGraduação e Pesquisa.

O interesse e colaboração da professora Victoria Herskovitiz, presidente daquela Câmara, contribui para sua rápida e favorável manifestação. Em reuniões com nosso grupo, ela nos deu preciosa orientação a respeito da montagem final do projeto. Me empenhei denodadamente em vê-lo aprovado ainda em minha gestão. O que se deu em nível da Universidade.

Todavia, mesmo que sob o ponto de vista legal, fosse suficiente a aprovação da Universidade para sua implantação, resolveu-se, inclusive com a recomendação da Câmara, submeter o processo à apreciação da CAPES. Sua aprovação, tornaria viável a obtenção de bolsas para nossos futuros alunos.

Transcorrido quase um ano, como a CAPES não se manifestasse, não 
obstante nossa insistência, o curso foi criado, em 1991. Inicia-se, formalmente, a terceira fase da pós-graduação em Antropologia na UFRGS. Na época a comissão coordenadora do Programa era composto Claudia Fonseca, Ari Pedro Oro e Ruben Oliven, sob a coordenação da primeira.

Bem depois recebemos, por fim, a manifestação da CAPES, através dos relatórios de dois consultores. Os relatórios eram conflitantes. Enquanto um, no conjunto, era favorável e sugeria medidas para superar problemas menores, o outro era totalmente negativo, expresso em redação agressiva e mesmo raivosa.

Face a situação, buscou-se junto à CAPES o envio de uma comissão de consultores para, in loco, discutir-se a questão. Vieram a professora Marisa Peirano, da UnB e o professor Octávio Velho, do Museu Nacional/UFRJ. Avaliadas todas as questões e incorporadas as sugestões dos consultores, o curso obteve a recomendação da CAPES, em 1993. Suas principais sugestões foram a contemplação de estudos camponeses e de sociedades indígenas, no currículo.

Como se deu quando da implantação do mestrado, o professor Octávio Velho proferiu a aula inaugural que implantava o doutorado, em março de 1994. Atualmente o doutorado tem sete alunos, com as primeiras teses previstas para o final de 97/início de 98. Dando continuidade à procura de nosso Programa por estudantes de fora do Estado, destes sete doutorandos, apenas um tem vinculação institucional no Rio Grande do Sul. Dos demais, dois são do Estado do Espírito Santo, sendo da Argentina, Cabo Verde, Chile e Uruguai os outros quatro.

Quanto ao Mestrado, o Programa já titulou sessenta e cinco mestres.

Apesar de aposentado, continuo vinculado ao Programa, por conta de afetos recíprocos. Desta minha nova etapa entendo relevante registrar dois fatos em que tive/tenho atuação.

O primeiro foi a coordenação da V Reunião de Antropologia do (Merco) Sul, na realidade a I Reunião de Antropologia do Mercosul, promovida pelo Programa de Pós-Graduação em Antropologia Social da UFRGS, e tendo por tema Cultura e Globalização. O evento foi realizado em setembro de 1995, em Tramandaí, cidade litorânea, a cerca de 120 km ao norte de Porto Alegre. Foi determinante para escolha deste local o fato de puder se utilizar as instalações da Colônia de Férias da UFRGS aí existente.

Antes de dar outras informações sobre esta I Reunião de Antropologia do Mercosul se impõe informar seus antecedentes.

Tudo começou numa Reunião da ANPOCS em 1986. Instigado por nosso Programa, o Programa homônimo da Universidade Federal de Santa Catarina 
promoveu, em 1987, a I Reunião de Antropologia do Sul do Brasil, chamada de ABA-SUL ou mesmo de ABINHA-SUL.

É oportuno registrar que o professor Arthur Rambo, modesto e quase tímido, foi uma das “estrelas” deste evento. Apresentou um trabalho sobre a educação nas colônias alemãs no Rio Grande do Sul, que foi publicado por Cadernos de Estudos, que será identificado mais adiante. Suas considerações sobre a racionália, disciplina que tratava de práticas e habilidades para a vida cotidiana, despertaram interesse generalizado. Na mesma publicação ele também divulgou uma outra importante pesquisa sobre o associativismo naquelas comunidades.

Para não confutar com as reuniões da Associação Brasileira de Antropologia - ABA -, realizadas nos anos pares, as da ABINHA-SUL foram programadas para os anos ímpares. Elas deveriam se realizar em sistema de rodízio e nesta ordem, entre os Programas/Departamentos de Antropologia, da Universidade Federal de Santa Catarina, Universidade Federal do Rio Grande do Sul e Universidade Federal do Paraná. Assim a reunião de 89 foi realizada na UFRGS, a de 91 na UFPR e a de 93 na UFSC. Registro que em todas elas havia crescente participação de professores e alunos dos outros países que junto com o Brasil integram o Mercosul.

De tal modo, quando chegou a nossa vez de realizar a reunião de 95, entendemos de transformá-la de regional em internacional.

Sua programação acadêmica foi composta por 2 conferências, 6 mesas redondas, 18 grupos de trabalho, 1 oficina, 12 exposições fotográficas e 14 mostras de vídeos. Ao todo foram apresentadas 272 comunicações. A reunião contou com a presença de aproximadamente 500 pessoas, de 14 Estados do Brasil e de mais 12 países, sendo 375 os congressistas inscritos, com 55 filiações institucionais.

A conferência de abertura, proferida pelo professor Marc Auge, professor e na oportunidade diretor da École des Hautes Études en Sciences Sociales, França, e intitulada “L'anthropologie aujourd'hui”, está publicada em Horizontes Antropológicos n. 3.

A partir de proposição apresentada nesta primeira reunião, a segunda será realizada em Piriápolis, no Uruguai, no período de 11 a 14 de novembro de 1997, tendo por tema Fronteras Culturales y Cidadania. Tudo indica que a III Reunião será realizada na Argentina.

A foto a seguir, feita em frente a Colônia de Férias da UFRGS, em Tramandaí mostra a equipe que organizou e/ou trabalhou no evento. 


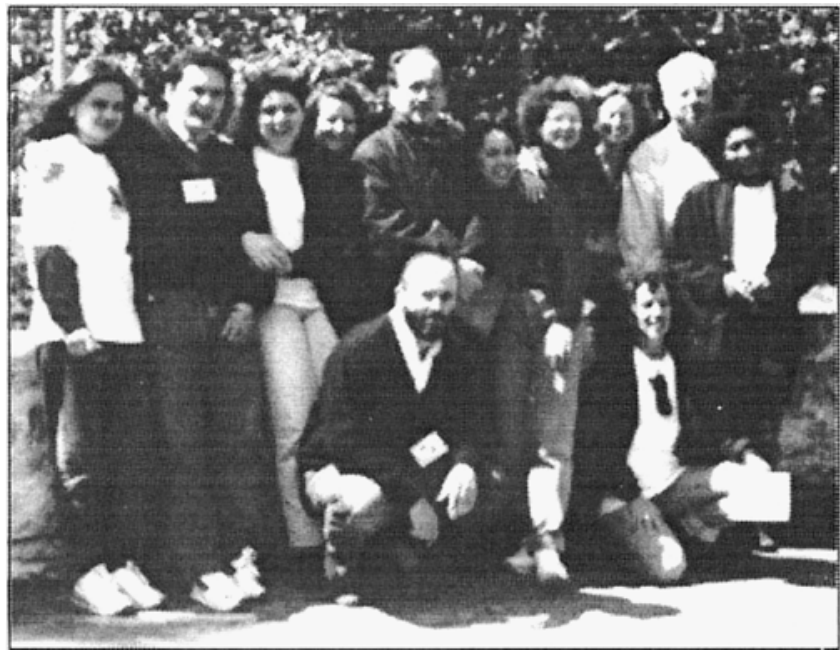

I Reunião de Antropologia do Mercosul - Iramandaí - 1995. Da direita para a esquerda: (em pé) Mima Rosa, Sérgio Teixeira, Claudia Fonseca, Cornelia Eckert, Márcia Fagundes, Ruben Oliver, Maria Eunice Maciel, Patrícia Faria, Paulo Terra, Gisele Flores. Sentados: Daisy Barcelos e Alexandre Aguiar (foto do arquivo Projeto História da Antropologia no RS - UFRGS).

O segundo fato a que quero me referir é exatamente a Horizontes Antropológicos, cujo primeiro número foi publicado em 1995, e que marca concretização de um projeto de longo prazo do Programa: a edição regular de uma revista.

A concretização de tal projeto foi estimulada pelo desafio e apoio propostos pelo Programa de Apoio à Editoração de Periódicos, concebido em 1994 pelo professor José Vicente Tavares do Santos, quando Pró-Reitor Adjunto de Pesquisa e Pós-Graduação da UFRGS.

Horizontes Antropológicos tem raízes em duas outras publicações anteriores do Programa. Uma é Caderno de Estudos, vindo do tempo do Curso de Pós-Graduação em Antropologia, Política e Sociologia e encerrada em 1989. Mimeografado, de aparência modesta e com tiragem reduzida, chegou a 14 números. A outra é Cadernos de Antropologia, surgido em 1990 e encerrada em 1994. Com boa qualidade gráfica, inclusive com capa à cores, e com tiragem em torno de 200 exemplares, teve 12 números publicados.

Aceito o desafio de participar do Programa de Apoio à Editoração de Periódicos, decidiu-se encerrar a publicação de Cadernos de Antropologia e 
lançar Horizontes Antropológicos. Como eu já era o editor daquele, pareceu natural que assumisse a responsabilidade de editor da nova publicação, como se deu.

Ao preencher o formulário com informações básicas sobre a nova revista, para enviar àquele Programa, me ocorreu que Horizontes Antropológicos seria melhor do que o nome para ela escolhido (e que não lembro) pela Comissão Editorial. Consultados na hora e individualmente cada um de seus integrantes, como todos concordaram, foi adotado o novo nome.

A leitura das orientações para possíveis colaboradores, no final da revista, fornecerá aos interessados informações relevantes a seu respeito.

Sendo este depoimento centrado em minha vivência na Antropologia, entendo imperativo falar de minhas publicações. Elas são compostas por um livro e vinte e um artigos. Apresento o livro e dois dos artigos que julgo mais relevantes. Os três enfocam seus temas como rituais seculares, que é também área de meu maior interesse.

O livro é Os recados das festas: representações e poder no Brasil. Rio de Janeiro, FUNARTE/Instituto Nacional do Folclore, 1988. Este trabalho foi contemplado com o Prêmio Sílvio Romero-1987, como vencedor do concurso de mesmo nome, promovido pelas instituições que o editaram, conforme normas do mencionado concurso.

O livro apresenta um estudo abrangente de festas urbanas para produtos agrícolas no Brasil, com a etnografia centrada nas festas da Bergamota, Feijão, Melancia, Soja e Uva, no Rio Grande do Sul. As duas últimas de caráter nacional.

Entendo útil destacar que o trabalho contempla uma ampla análise estrutural comparativa das representações sobre dois tipos sociais da maior relevância para a história social do Rio Grande do Sul: gaúchos e colonos.

Os artigos são:

“Vestibular: ritual de passagem ou barreira ritualizada?” In Ciência e

Cultura, 1981, 33, 12, 1574-1580.

O trabalho aborda o vestibular como evento que mobiliza interesses substantivos e emoções intensas de muitos milhares de pessoas no Brasil. Conclui que, apresentado e percebido como um ritual de passagem, o vestibular, na realidade, se constitui em barreira ritualizada ao ingresso no ensino superior, mascarando carências de vagas e eficiências/deficiências no preparo dos candidatos.

“O simbolismo essencial das brigas de galo”. In Horizontes

Antropológicos, n. 6, Porto Alegre, PPG. Antropologia Social/UFRGS, 1997. 
O trabalho, que considera as brigas de galos como fato social relevante, encontra na exaltação de atributos como coragem, brio, estoicismo e coisas no gênero, o simbolismo essencial das brigas de galos, como coisa que lhe é inerente. Tais atributos são pensados como definidores da masculinidade moral.

A meu juízo, na área das ciências sociais, este é o trabalho mais abrangente sobre o tema.

Encerrando a parte etnográfica deste depoimento julgo não ser excessivo registar a composição do Departamento de Antropologia, do corpo docente do Programa de Pós-Graduação em Antropologia Social da UFRGS e os órgãos de pesquisa que o integram.

Composição do Departamento de Antropologia:

Ari Pedro Oro - Universidade de Paris III - França.

Bernardo Lewgoy* - Universidade de São Paulo - Brasil.

Carlos Alberto Steil - Museu Nacional - Universidade Federal do Rio de Janeiro - Brasil.

Ceres Gomes Víctora - Universidade Brunei - Inglaterra.

Claudia Lee Williams Fonseca - Universidade de Paris X - França.

Cornelia Eckert - Universidade de Paris V - França.

Daisy Macedo de Barcellos - Museu Nacional - Universidade Federal do Rio de Janeiro - Brasil.

Denise Fagundes Jardim* - Museu Nacional - Universidade Federal do Rio de Janeiro - Brasil.

José Otávio Catafesto* - Universidade Federal do Rio Grande do Sul - Brasil.

Luis Ricardo Michaelsen Centurião - Pontifícia Universidade Católica do Rio Grande do Sul - Brasil.

Maria Eunice do Souza Maciel - Universidade de Paris V - França. Ondina Fachel Leal - Universidade da Califórnia/Berkeley - EUA. Oscar Alfredo Agüero (visitante) - Universidade de Upsala - Suécia. Ruben George Oliven - Universidade de Londres - Inglaterra.

Sérgio Batista* - Universidade de São Paulo - Brasil.

Obs.:* realizando doutorado.

Corpo docente do Programa de Pós-Graduação:

Ari Pedro Oro - Universidade de Paris III - França.

Carlos Alberto Steil - Museu Nacional - Universidade Federal do Rio de Janeiro -Brasil. 
Ceres Gomes Víctora - Universidade Brunei - Inglaterra.

Claudia Lee Williams Fonseca - Universidade de Paris X - França.

Cornelia Eckert - Universidade de Paris V - França.

Daisy Macedo de Barcellos - Museu Nacional - Universidade Federal do Rio de Janeiro - Brasil.

Daniela Knauth - École des Hautes Études en Sciences Sociales - França.

Maria Elizabeth Lucas - Universidade do Texas - EUA.

Maria Eunice do Souza Maciel - Universidade de Paris V - França.

Odaci Luiz Coradini - Museu Nacional - Rio de Janeiro - Brasil.

Ondina Fachel Leal - Universidade da Califórnia/Berkeley - EUA.

Oscar Alfredo Agüero (visitante) - Universidade de Upsala - Suécia.

Ruben George Oliven - Universidade de Londres - Inglaterra.

Sérgio Alves Teixeira - Universidade Estadual de Campinas - Brasil.

A origem acadêmica deste conjunto de professores, por si só, é garantia de sua alta qualificação e não abriga os prejuízos inerentes à endogenia. Coisa, aliás, com que sempre nos preocupamos no Programa.

Órgãos que integram o Programa de Pós-Graduação:

Laboratório de Antropologia.

NACI - Núcleo de Antropologia e Cidadania.

NAVISUAL - Núcleo de Antropologia Visual

NER - Núcleo de Estudos da Religião.

NUPACS - Núcleo de Pesquisa em Antropologia do Corpo e da Saúde

NUPECS - Núcleo de Pesquisa Sobre Culturas Contemporâneas.

NIT - Núcleo de Antropologia das Sociedades Indígenas e Tradicionais. Obs. O Laboratório de Antropologia foi criado em 1989, durante minha gestão como coordenador do Programa e os demais a partir de 1993. O Laboratório conta também com a colaboração de Ana Luiza Rocha, antropóloga da UFRGS, com doutorado pela Universidade de Paris V, França.

Dando por encerrada a etnografia, passo às considerações.

O ponto de partida para este depoimento serve também de ponto de partida para minhas considerações. A comunicação de Ruben e Maria Eunice, de que haviam decidido que eu deveria prestar este depoimento, ilustra, emblematicamente, a cultura da proximidade pessoal e do compromisso com a Antropologia, de todos os seus integrantes. E não se trata de figura de retórica. Isto faz com que, no plano institucional, as divergências não resultem em 
conflitos e que a tarefa de carregar o piano da Antropologia é de todos. Seguindo com a metáfora do piano, corriqueira entre nós, este é um piano único: ele estimula seus carregadores a fazê-lo crescer. Me permito dizer que a metáfora é perfeita.

Deixando o campo das representações, apresento um caso exemplar de sua materialização: as circunstâncias da ida de Cornelia Eckert para fazer doutorado na França, pelo nosso Projeto no Acordo CAPES/COFECUB.

Intencionalmente não abordei o episódio na parte da etnografia, para melhor destacá-lo aqui.

Concedida a primeira bolsa de doutorado para nós eno primeiro ano da efetiva implantação acadêmica de nosso Projeto (em 85 houve apenas a implantação administrativa, com as missões de identificação pelos coordenadores), era imperativo que apresentássemos um candidato. Cornelia, que havia sido admitida em março 86, era nosso único candidato disponível. Mesmo pega de surpresa e sem nenhum conhecimento de francês, ela foi sensível a meu apelo, assumiu a missão, viajando em setembro para lá. O modo como as coisas se passaram justifica falar em missão. Mesmo integralmente bem-sucedida e decorrido tanto tempo, não é excessivo, novamente, agradecer e cumprimentá-la por tudo.

Não é demais destacar que, rompendo uma norma muito arraigada de estudantes brasileiros no exterior, de fazerem pesquisas para suas teses no Brasil, ela também fez pesquisa na França. Elaborou uma ampla e excelente tese, comparando o universo simbólico de mineiros de carvão no Brasil e França.

Os compromissos do grupo com Programa é coisa tão natural que eles podem se somar ao desempenho de tarefas por si exigentes. Isso foi o caso por exemplo, de Maria Eunice Maciel, que no andamento de seu doutorado, foi zelosa em oportunizar facilidades para seus colegas que cumpriram missão de trabalho na França na época (com destaque para a obtenção de alojamento) e indicação de bibliografia que nos seriam enviadas pelo Acordo CAPES/COFECUB.

A responsabilidade pela organização de Horizontes Antropológicos, já assumida ou por assumir pelos integrantes do programa se enquadra no mesmo compromisso.

Como uma questão que sempre me intrigou foi a modéstia de desafios institucionais apresentados pela Universidade a seus vários seguimentos, aproveito para abordá-la aqui.

Em toda a minha vivência na Universidade quase não vi a proposição de tais desafios. No que se refere à Antropologia, exceto pelas solicitações de gastar uma certa verba em curto espaço de tempo, para evitar sua devolução por falta de uso, o único desafio que lhe foi apresentado, foi o do Programa de 
Apoio à Editoração de Periódicos.

Em compensação, quase todos os desafios, individuais ou grupais que nos impusemos, quando solicitado, obteve, quase sempre, seu apoio pronto e indispensável.

Organização de eventos internos, participação em eventos externos, assinatura de convênios, afastamento para cursar pós-graduação, criação de cursos de pós-graduação, saídas para pesquisa de campo, se incluem na lista de nossos múltiplos pleitos. Muitos foram diretamente apresentados por mim.

As modalidades de apoios também foram múltiplas, como dinheiro, veículos, espaços físicos, facilidades administrativas. Não poucas vezes os Gabinetes de Pró-Reitores e do próprio Reitor agiram para superar entraves administrativos, em especial fora da Universidade, como Ministério da Educação e CAPES.

Como o apoio dos funcionários também foi relevante para as realizações da Antropologia, especialmente nesta época em que eles e os serviços públicos são objetos de ataques generalizados, como ineficazes, desnecessários, onerosos e coisas no gênero, preciso dizer que minha experiência na UFRGS não corrobora tal visão. No caso dos funcionários, os desinteressados e incompetentes representam a exceção que confirma o que é dito ser a regra.

$\mathrm{O}$ apoio generalizado às solicitações apresentadas à Universidade como compensação à modéstia dos desafios por ela propostos, mostra que ela convive bem com as lideranças espalhadas por todos seus seguimentos. Digo mais, conta com elas para seu próprio crescimento.

Porque a Antropologia bem compreendeu a questão e não lhe faltou liderança, dela beneficiou-se enormemente. Ou melhor, como tem várias lideranças, continua a beneficiar-se de seu trabalho.

Encerrando este depoimento me ocuparei especificamente da liderança na Antropologia no período de 78 a 92. Dois motivos me levam a fazer este recorte no tempo: conhecê-lo bem e porque foi neste período que a Antropologia da UFRGS se consolida como centro avançado de investigação, com reconhecimento nacional e mesmo internacional.

Os fatos, se por um lado, me obrigam, constrangido, a falar de mim como um de seus líderes, neste período tão importante; por outro lado, também me obrigam, agora a vontade e com satisfação, a falar de Ruben George Oliven, como o seu outro líder. Em conjunto, ou separadamente, mas sempre com harmonia, lideramos a Antropologia no período. Aliás, ele continua a fazê-lo, só que agora e felizmente, com muito mais companhia.

A percepção comum que nossas realizações profissionais se confundiam 
com o crescimento da Antropologia, nossa disposição para o trabalho, nossa afinidade pessoal e mútuo respeito, fizeram com que nos empenhássemos por tal crescimento.

Basicamente, porque nosso trabalho beneficiava a Antropologia como um todo e porque dominávamos o trato das questões político-adminstrativas, o reconhecimento de nossa liderança, por todos os demais colegas, se deu como coisa muito natural. A credencial de pais fundadores, que Claudia Fonseca nos atribui, espelha bem a situação.

Compartilhando afinidades e salas de trabalho, desde o tempo do cubículo, Ruben e eu aprendemos a trabalhar juntos, formando uma dupla muito afinada. Com extrema facilidade tomávamos decisões e reformulávamos pontos de vistas. $\mathrm{O}$ entendimento comum permitia que certas decisões individuais fossem comunicadas ao outro, com a certeza de acolhimento pronto.

Precisando bem as coisas é preciso dizer que a minha atuação se deu mais em nível da própria Universidade, ao passo que Ruben atuou aí e também fora dela. $\mathrm{O}$ fato de eu não ter doutorado limitava meu raio de ação. Ainda assim tive alguma presença externa, inclusive integrando a diretoria da Associação Brasileira de Antropologia, quando presidida por Roque Laraia, no período 1990/1992.

Em nível interno, é de justiça dizer que a implantação do mestrado, mais do que liderada por ele, foi uma conquista dele. Em nível externo, em instâncias como ABA, FINEP, ANPOCS, CAPES, CNPq, fóruns internacionais, sua contribuição foi maiúscula.

Ambicioso, habilidoso e competente, ele soube, como ninguém, sem jamais descurar de seus interesses pessoais, compatibilizá-los com os do Programa.A construção de sua carreira, sem sombra de dúvida, a mais destacada na Antropologia da UFRGS, sempre somou para sua base institucional.

Com tais destaques não estou negando nem minimizando a relevância de outras lideranças expressivas, em qualquer época. Não fossem elas, simplesmente, muito pouco haveria o que destacar na Antropologia da UFRGS.

Como indicado há pouco, hoje são muitas e expressivas as lideranças na Antropologia. Nominalmente basta citar Claudia Fonseca, que preside o Comitê da Capes para a Antropologia. Genericamente me refiro a todos os outros integrantes do Programa, responsáveis diretos pela criação e atuação de seu Laboratório e Núcleos de Pesquisa, com qualificada produção e ativa participação acadêmica.

Finalizando, penso que nestas considerações, se encontra a resposta para a questão formulada pelos consultores da Capes, a que já me referi de como tão poucos puderam realizar tanto, e que o mesmo continue a ocorrer. 